\title{
The abscopal effect of local radiotherapy is induced by TGF $\beta$ blockade
}

\author{
Julie Diamond $^{1 *}$, Claire Vanpouille-Box ${ }^{1}$, Mary Helen Barcellos-Hoff ${ }^{2}$, Silvia C Formenti ${ }^{2}$, Sandra Demaria ${ }^{1}$ \\ From Society for Immunotherapy of Cancer 28th Annual Meeting \\ National Harbor, MD, USA. 8-10 November 2013
}

Radiotherapy (RT) is employed to achieve local cancer control. However, in rare patients, regression of metastases outside of the radiation field has been reported after irradiation of one tumor site, a phenomenon known as abscopal effect. We have previously shown in experimental tumor models that the abscopal effect is mediated by activation of anti-tumor immune responses by radiotherapy, which can convert the irradiated tumor into an in situ vaccine. However, effective induction of anti-tumor immunity by radiation is rare. To study the barriers to the induction of an abscopal effect we have employed a mouse model of metastatic breast cancer. Ionizing radiation activates Transforming Growth Factor- $\beta$ (TGF $\beta$ ), a strongly immunosuppressive cytokine that promotes DNA damage repair (DDR) and metastasis. We therefore hypothesized that neutralization of TGF $\beta$ may improve the development of anti-tumor immune responses induced by RT, leading to an abscopal effect. To test this hypothesis, mouse mammary carcinoma TSA cells were injected s.c. at day 0 into syngeneic immunocompetent BALC/c mice at two separate sites, a "primary" site that was irradiated, and a secondary site outside of the radiation field. TGF $\beta$ neutralizing 1D11 mAb was given i.p. starting one day before radiation. On day 12 when both tumors were palpable, mice were randomly assigned to groups receiving either $1 \mathrm{D} 11 \mathrm{mAb}$ or isotype control (MOPC-21) every other day for 16 days, with or without radiation (6 Gy doses given to the primary tumor on days 13-17). Radiation alone effectively delayed primary but not secondary tumor growth. 1D11 alone did not have a significant effect on either primary or secondary tumors. Combination of 1D11 with RT enhanced significantly inhibition of the primary irradiated tumor, with complete tumor regression in 4 out of 6 mice by day 28 ( $p=0.0059$ radiation $+1 \mathrm{D} 11$ versus radiation). Importantly, an abscopal effect was seen only in mice

${ }^{1}$ Pathology, NYU School of Medicine, New York, NY, USA

Full list of author information is available at the end of the article treated with radiation + 1D11, with significantly smaller secondary tumors on day $28(\mathrm{p}=0.0329$ radiation $+1 \mathrm{D} 11$ versus MOPC-21). Data indicate that blocking TGF $\beta$ in the context of radiation not only improves local tumor control, but also induces an abscopal effect with systemic tumor inhibition. Overall, data provide further support for the use of agents targeting TGF $\beta$ during radiotherapy, a concept currently tested in a phase I/II clinical trial in metastatic breast cancer patients (NCT01401062).

\section{Authors' details \\ ${ }^{1}$ Pathology, NYU School of Medicine, New York, NY, USA. ${ }^{2}$ Radiation \\ Oncology, NYU School of Medicine, New York, NY, USA.}

Published: 7 November 2013

doi:10.1186/2051-1426-1-S1-P115

Cite this article as: Diamond et al:: The abscopal effect of local

radiotherapy is induced by TGF $\beta$ blockade. Journal for ImmunoTherapy of Cancer 2013 1(Suppl 1):P115.

Submit your next manuscript to BioMed Central and take full advantage of:

- Convenient online submission

- Thorough peer review

- No space constraints or color figure charges

- Immediate publication on acceptance

- Inclusion in PubMed, CAS, Scopus and Google Scholar

- Research which is freely available for redistribution
C Biomed Central

두 2013 Diamond et al; licensee BioMed Central Ltd. This is an Open Access article distributed under the terms of the Creative Commons Attribution License (http://creativecommons.org/licenses/by/2.0), which permits unrestricted use, distribution, and reproduction in any medium, provided the original work is properly cited. 